\title{
Irregularity of the <ie> spellings in West Saxon English: Remarks on variation in third-person pronouns
}

\author{
Marco Condorelli \\ University of Central Lancashire
}

Orthographic consistency was rarely maintained in most Old English varieties, because the language system was relatively new and spelling norms took time to develop. While full standardisation is never expected in Old English, the understanding of factors underlying patterns of regularity and irregularity are paramount for a full grasp of issues pertaining to authorship, textuality and other linguistic and non-linguistic levels of analysis. These notes explore spelling irregularity in material from West Saxon dialects, bringing comparative examples of variation in spelling between early West Saxon (eWS) <ie $>$ and late West Saxon (IWS) $<$ y $>$. West Saxon generally stands up for its emphasis on some degree of orthographic standardisation and yet appears to display interesting patterns of variation. The focus of my notes will be on particular instances of spelling inconsistencies, with special attention to a specific category of words where <ie> appears to vary more frequently, namely third-person pronouns. For my exploratory analysis, various witnesses of the Anglo-Saxon Chronicle (i.e. examples of eWS and IWS texts) were compared. The data was collected from different sections of an orthography-friendly edition of four different manuscripts, MSA (Bately 1986), MSB (Taylor 1983), MSC (O’Brien O’Keefe 2001) and MSD (Cubbin 1996), and compared with digital copies of the original manuscripts. The latter part of these notes points to some of the factors which could explain the features detected, with an exhortation for future researchers to build on some of the ideas proposed and explore new territory.

Keywords: Old English; spelling; pronouns; variation; early West Saxon; late West Saxon

Marco Condorelli, Selim24 (2019): 29-52.

ISSN 1132-631X / DOI https://doi.org/10.17811/selim.24.2019.29-52 


\section{Preliminaries: Phonological insights}

The late West Saxon dialect began to be used in writing from the second half of the tenth century and became the first 'standardised' written English (Gneuss 1986: 46). The use of a regularised form of Old English entailed the adoption of different conventions, which evolved over time and affected different linguistic levels, not least spelling. These notes concern irregularity in West Saxon orthography and provide a preliminary investigation into variation in spelling between the typical eWS <ie> and IWS <y>. The eWS and IWS dialects are most likely not lineally descendents and the relationship between the two dialects is doubtlessly complex (cf. Hoad 2014), which means that the term 'standardisation' should be used with caution and more preferably replaced with words like 'regularisation' and 'conventionalisation' with particular reference to IWS. Regardless of these caveats, eWS and IWS are expected to have some relationship with each other, albeit looser than previously assumed. In light of these remarks, my notes explore a diachronic relationship between eWS and IWS drawing on different versions of the same texts available in the Anglo-Saxon Chronicle (Dumville \& Keynes 1983-2001), which allow for a preliminary, more systematic comparison of <ie>-spelling patterns across different hands and across several years in the two varieties.

The general agreement regarding the regularisation of $<$ ie $>$ in West Saxon is that eWS <ie $>$ generally corresponds to IWS $<\mathrm{y}>$, but it turns into $<\mathrm{i}>$ before palatals in IWS (Campbell 1959: §§302, Hogg 1992: §5.167). In eWS $<\mathrm{ie}>$ (and, sometimes, $<\mathrm{i}>$ ) is more frequent, and in IWS $<\mathrm{y}>$ (and, occasionally, <i>) is usually used. However, the matter is not so straightforward: each graph has particular phonetic realisations in eWS and IWS, which are sometimes overlapping and inconsistent. The supposed phonetic signification of each graph as interpreted in traditional grammars is illustrated in Figures 1-5, with hope that the graphic framework will help the reader to make more sense of the complexities of the phonological relationships in question. 
eWS:

Figure 1. eWS <ie>

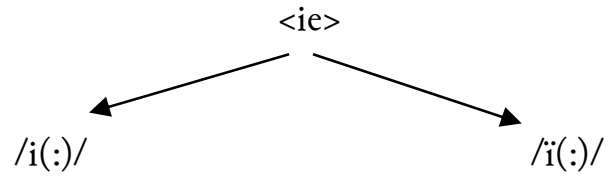

It is doubtful whether eWS <ie> (from whatever source, either diphthongal (cf. Lass 1994: 68-69, Kim 1984: 28-29) or monophthongal (Hogg 1992: §5.164)) merged with the sound normally represented by $<\mathrm{i}>$, namely $/ \mathrm{i}(:) /$, or whether it represented a different phoneme. Some $<$ ie > spellings seem to appear for $/ \mathrm{i}(:) /$, such as in gietsian, biene and biera (Campbell 1959: §§300, 703; Hogg 1992: §§5.167, 5.172).

Figure 2. eWS $<\mathrm{i}>$

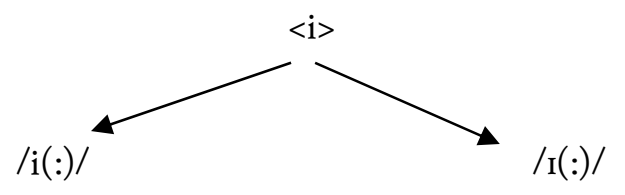

This is the normal phonetic realisation of $<\mathrm{i}>$ in eWS, for example in biran (Hogg 1992: $\S 5.171)$.
Hogg (1992: §5.171) also suggests this phonetic realisation, with no specifications regarding when it occurs.
Perhaps a laxed (i.e. centralised and lowered) form of $/ \mathrm{i} /$ which occurs sporadically in eWS (Hogg 1992: $§ 5.175$, though Hogg expresses uncertainty about this potential phonological value). 
Figure 3. eWS $<y>$

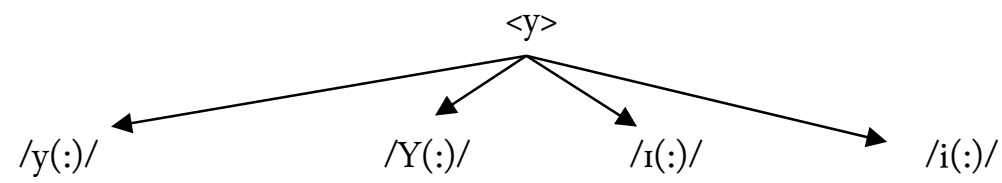

This indicates rounding and it is less frequent in eWS. The $<y>$ spelling usually occurs, in eWS, between a labial sound and $/ \mathrm{r} /$, for instance

wiernan > wyrnan (Campbell 1959: §315, Hogg 1992: §5.166).
According to Hogg (1992: $\S \S 170-175),<y>$ can also indicate laxness, not just rounding. However, laxness is sporadic in eWS. It is not clear in which circumstances /Y(:)/ and /I $(:) /$ alternate. In general, however, a distinction between $/ y(:) /$ and $/ \mathrm{Y}(:) /$ seems less likely than the other values.
This usually occurs only with a preceding /w/ or /r/ (e.g. wille and ribt) and in weakly-stressed forms, such as syððan (Hogg 1992: §5.170).

\section{IWS:}

According to Hogg (1992: §5.163), the phonological significations of $<$ ie $>$ in IWS probably merged with those of $<y>$ :

Figure 4. IWS <ie, y>

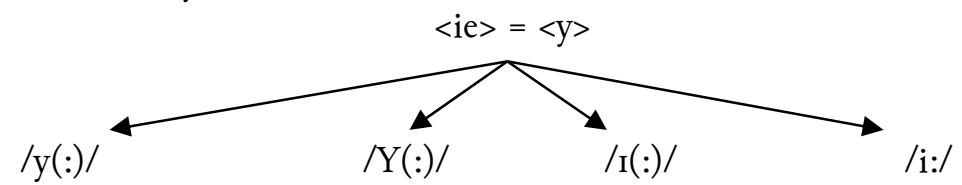

For Campbell (1959: $\S 318)$, IWS $<y>$ indicates rounding of $/ \mathrm{i}(:) /$, often in the neighbourhood of labials and before /r/ (e.g. clypian).
In IWS, there is a greater tendency to laxness, especially in low stress environments, but, occasionally, even under primary stress (Gradon 1962: 75, Hogg 1992: §§170-173).
According to Hogg (1992: §5.170), this occurs only occasionally. 
Figure 5. IWS <i>

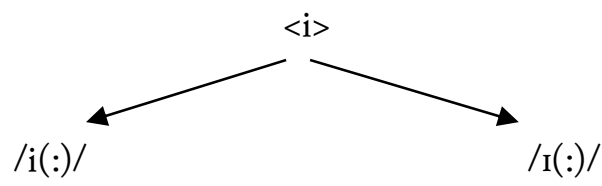

$$
\begin{aligned}
& \text { This generally occurs before } \\
& \text { palatal consonants such as /x/ } \\
& \text { (hence, miebt > mibt, where } \\
& <\mathrm{h}>=/ \mathrm{x} / \text { ) (Campbell 1959: } \\
& \S 316 \text {, Hogg 1992: } § 5.163) \text {. }
\end{aligned}
$$

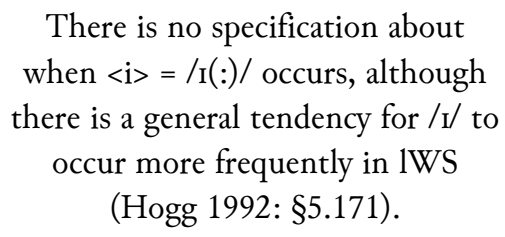

There is no specification about when $<\mathrm{i}>=/ \mathrm{I}(:) /$ occurs, although there is a general tendency for $/ \mathrm{I} /$ to occur more frequently in IWS

(Hogg 1992: §5.171).

The information provided in Old English grammars is by no means the last word on the topic, as there appears to be a longstanding, parallel debate on the spellings in research-oriented publications, almost exclusively focussed on phonological explanations. Lewenz (1908) started off the dialogue suggesting that eWS <ie> and IWS <y> usually occur in the vicinity of labials (e.g. bielpeð), sonorous dentals (e.g. byrð) and in weakly-stressed words (e.g. biene). The phonetic indication of graphs like <ie> in West Saxon has then continued to be a subject of debate in work published closer to our present day with focus on Old and Middle English (see e.g. Pilch 1970; Kim 1984; Colman 1985, 1987, 1988, 1992, 1994, 1997; Voss 1995; Horobin \& Smith 2002: 48, 63; Lass \& Laing 2005; Fulk 2012: $\$ 10,20)$, but the matter seems to have been more formally settled in some recent discussion of <ie> scattered throughout the Corpus of Narrative Etymologies (CoNE), produced at Edinburgh by a team including Roger Lass and Margaret Laing. The position expressed in CoNE is that the only reasonable value for $<$ ie $>$ is [iy] and that the sound later split into $[\mathrm{i}(:)]$ and (probably) $[\mathrm{y}(:)]$, if their respective graphic indications - the western early Middle English spellings with $<$ u $>$ and $<$ ui $>$ do in fact indicate a front rounded vowel. At any rate the [iy] type (common for instance in large parts of the southern US) seems to give the most sensible history (cf. especially the change labelled IES (ie-split) in the CoNE subcorpus of phonological changes), though this conclusion did not come about without a great deal of rethinking and revisiting of the authors' own ideas over time. Regardless of the complexity of the scenario at hand, however, the current 
understanding of the spellings in question as belonging to lineally disjoint varieties of West Saxon and possibly representing different phonological values appears to be an essential, yet sufficient basis for an informed exploratory and comparative investigation of spelling consistency and irregularity in the AngloSaxon Cbronicle. The Cbronicle is the backbone of Old English literature and history surviving to our present day (Jorgensen 2010a: 1) and represents an extremely useful resource for insights into spelling variation from cross-textual points of view. It is hoped that some of the insights into the patterns and issues referenced to in these notes will encourage others to frame new perspectives and questions that are not necessarily tied solely to phonology. The aim will be that of encouraging a comparative discussion on the underrated category of pronouns as evidence for spelling change in the Chronicle, at a moment in time where spelling appears to have lost some momentum in the early English scholarly scenario.

\section{Remarks on samples from the Anglo-Saxon Chronicle}

In order to investigate patterns of variation in <ie>, sections from editions of various witnesses of the Chronicle were analysed, which are conventionally identified as MSA (Bately 1986), MSB (Taylor 1983), MSC (O’Brien O'Keefe 2001) and MSD (Cubbin 1996). The editions used are semi-diplomatic and do not present any variation in spelling from the originals (as clearly stated by the editors in the introductions to each edition above). Where sufficient legibility was possible, readings were also checked against facsimile copies of the original manuscripts in order to compare the faithfulness of transcription. The facsimiles are digital copies of the following manuscripts: Cambridge, Corpus Christi College, MS 173 (MSA), London, British Library, MS Cotton Tiberius A. vi (MSB), London, British Library, MS Cotton Tiberius B. iv (MSC), London, British Library, MS Cotton Tiberius B. i (MSD). ${ }^{1}$ The following table provides some additional details about the texts in question.

\footnotetext{
${ }^{1}$ Facsimile copies of these manuscripts are available in the British Library Online catalogue (https://www.bl.uk/manuscripts/) and the Parker Library on the Web (https://parker.stanford.edu/parker/actions/page.do?forward=home).
} 
Table 1. Details of the sources

\begin{tabular}{l|l|l}
\hline Manuscript & Date & Place of production (?) \\
\hline MSA: CCCC173 & c. 900 (eWS) & Winchester (Wessex) \\
\hline MSB: Cott. Tib A. vi & $977 \times 979$ (early lWS) & Perhaps Abingdon (Wessex) \\
\hline MSC: Cott. Tib B. i & c. 1050 (mid lWS) & Perhaps Abingdon (Wessex) \\
\hline MSD: Cott. Tib B. iv & c. 1050 (mid lWS) & $\begin{array}{l}\text { Perhaps Worchester (Mercia). } \\
\text { Although the location of MSD is } \\
\text { not in Wessex, the language of } \\
\text { this text still follows 'standard' } \\
\text { lWS }\end{array}$ \\
\hline
\end{tabular}

The selection of the samples above represents the safest option for a preliminary overview to minimise the influence of different hands, as the annals were selected at regular intervals among the sections that are most likely to have been written from a single scribe for each of the texts (Ker 1957: nos. 39, 188, 191, 192). This approach minimises the risk that any spelling inconsistency within the same source would be largely owed to the interference of different scribes. The specific annals chosen are [755], [871] and [885]; in MSB and MSC, [872] stands for [871] and [886] stands for [885] (MSA ff. 10r-15v, MSB ff. 11v-21v, MSC ff. 125r-133v, MSD ff. 22v$37 \mathrm{v})$. Although the date of entry is largely difficult to identify for all manuscripts in question, the sections selected are among those which can be identified with most confidence (cf. Taylor 1983, Bately 1986, Cubbin 1996, Dumville \& Keynes 1983-2001, O’Brien O’Keefe 2001).

The data available from these texts was analysed following two different steps. As a first step, the words with <ie> spellings in the above-mentioned sections from MSA were compared with the same words from the same sections in all of the other manuscripts by ordering them in a table (Appendix 1). The direct spelling comparison has shown a general variation pattern of ie $>y$ from eWS to IWS, with the proportion of eWS <ie> spellings decreasing and that of IWS $<\mathrm{y}>$ spellings increasing, in accordance with expected patterns for eWS and IWS respectively. The patterns drawn in Figure 6 suggest that the increase of $\langle y>$ spellings is not directly proportional to the decrease of $<$ ie $>$ spellings and that a considerable number of $<$ ie $>$ spellings follow additional

\footnotetext{
2 By 'standard' IWS, I refer to the 'Winchester standard', namely a prestigious written form with reasonably fixed spelling conventions originated in Winchester.
} 
alternations that are different from just $<y>$ in IWS, which again fits with more or less known patterns for eWS and IWS.

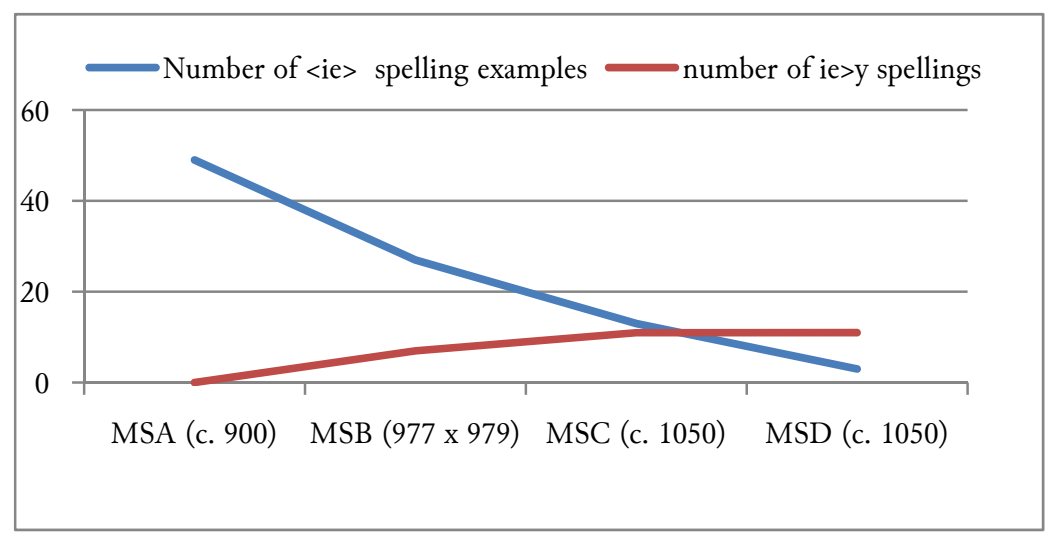

Figure 6. Number of <ie $>$ spellings and ie $>y$ spellings

Alternative spellings that were identified in IWS, i.e. $\langle$ ie $\rangle,\langle i\rangle$ and $\langle e o\rangle$, are overall greater in number than $\langle y\rangle$, as further illustrated in Figure 7 below.

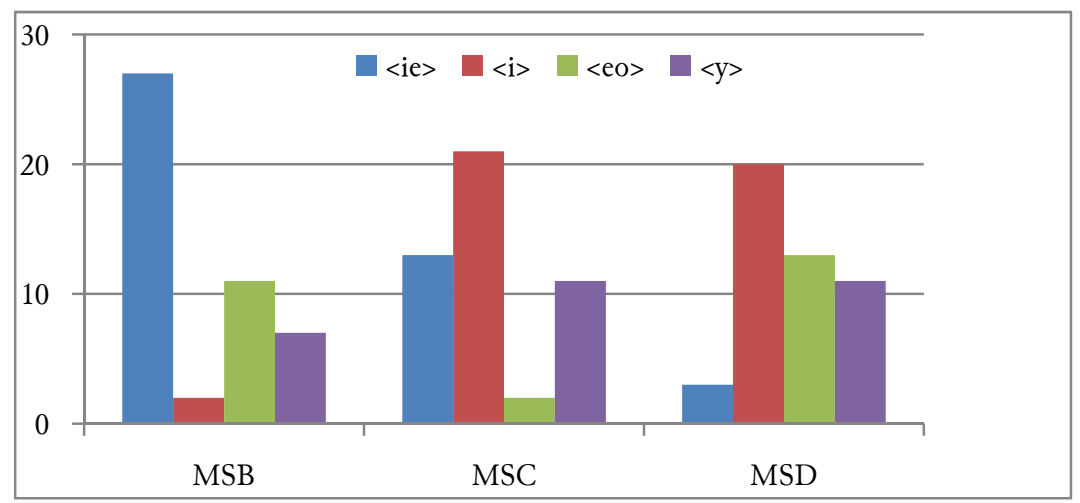

Figure 7. Number of different spellings found in sections from MSB, MSC and MSD

Despite the obvious differences in the proportions above, a general observation may be offered regarding the spellings at hand: the alternation between <ie> and $<y>$ appears to be generally more consistent for multisyllabic, stressed words, for example words like gebierdun (MSA (f. 10r)) > gebyrdon (MSB (f. 12r), MSC (f. 125v) and MSD (f. 23r)). Instead, variation appears much more 
frequent in pronoun forms $(86 \%$ of the relevant word material across the samples), and especially third-person pronouns as a category that represents examples of all variants detected, namely $\langle\mathrm{ie}\rangle,\langle\mathrm{eo}\rangle,\langle\mathrm{i}\rangle$ and $\langle\mathrm{y}\rangle$. As a second step of analysis, therefore, third-person pronouns were distributed in a table according to their case (Appendix 2). This enabled a comparison of spellings in identical morphological forms within and across the samples from all four copies. In MSA, bie indicates the third-person nominative and accusative plural pronoun; biera indicates the third-person genitive plural, and biene indicates the masculine accusative singular. The other texts compare as follows (for all of the texts, variation in all of the forms above occurs regardless of their orthographical environment):

- In MSB, the third-person nominative and accusative plural is consistently bie. A different form from MSA is used here for the third-person genitive plural, namely beora, and the masculine accusative singular, bine. Pronouns in the selected sections from MSB appear to be coherent in spelling, with some conventions appearing as different from those in MSA.

- In MSC, the forms bie and bi are used in free variation for the third-person nominative plural. The third-person genitive plural has four different forms: bira, biera, byra and beora. The masculine accusative singular is bine. As is evident, the chosen passages from MSC present varying pronoun spellings and there appears to be considerable change in conventions between the passages in MSC and those from the previous texts.

- In MSD, there is variation in the forms of the third-person nominative and accusative plural, by, beo, bie, bi. Heora and bine, instead, are used consistently for the third-person genitive plural and third-person masculine accusative singular, respectively. Sections from MSD, therefore, also appear to show some variation in pronoun spelling and conventions are different from those of the previous texts.

Patterns in personal pronouns are particularly interesting for addressing issues pertaining to the Chronicle. First of all, the frequency of variation in pronouns may not be entirely dependent on stress, as pronouns are not always weaklystressed forms, especially in longer sentence contexts (cf. Howe 1996: 87, cf. also Colman 1994 for insights into the relationship between stress and morphology). Rather, the fact that third-person pronouns appear more 
susceptible to spelling variation in the Chronicle could partially be a physiological symptom of their high frequency in the narrative context of the annals. These characteristics can be used to our advantage, as higher frequencies afford a cross-textual analysis with comparative insights into diachronic variation. Some of the spelling innovations detected in my samples are particularly useful examples to support previous statements on the relationship across the surviving texts, with possible concurring influences from earlier manuscript sources. Matters like the precise relationship of MSC to MSB and the place of MSA in the lines of transmission of the Chronicle have long been the subject of discussion and some disagreements (Bately 1991: 1). A general agreement among these resources, however, is that MSA, MSB and MSC are known to have the same core, i.e. up to 890 or 891 and a series of continuations to 914. The points of agreements and differences between MSB and MSC have led a number of scholars beginning from the father of modern studies on the Chronicle, Charles Plummer, to hypothesise that MSB and MSC especially were in fact derived from a now lost copy of the Chronicle (cf. Plummer 1979). The first part of this lost copy was in turn supposedly derived from an ancestor copy, which may also have been an ancestor copy of MSA and a possible common source of MSD. For the most part, however, the hand for the period up to 890 in MSD seems to have been influenced by a separate matrix text from the other three manuscripts, possibly a text from a northern scriptorium. From the tenth century onwards, instead, MSD appears to be a conflation of MSB and MSC with distinctive elements of its own (Bately 1991, Jorgensen 2010a: 5). In the samples surveyed across the four manuscript copies, the form beora is the dominant form of the third-person possessive in MSB and is also one of the forms existing in MSC and MSD. In light of the fact that beora is also the most dominant form in manuscripts of Ælfric and Wulfstan (cf. for example di Paolo Healey \& Venezky 1980), beora could indeed reflect the spellings already existing in the lost copy of the Chronicle which allegedly influenced MSA, MSB and MSC together with cross-textual interferences across the three copies (Bately 1991: 16). The spelling examples retrieved from MSD also appear to support a level of comparability of MSD with the other manuscripts, especially MSC. In the samples from MSC, IWS $b i$ appears as the most dominant form for the thirdperson nominative plural, yet the form bie, which is typical of MSA and MSB, also survives in nominative and accusative case and, in the nominative case, it appears almost as frequently as $b i$. The form $b i$ is in turn the dominant spelling in the samples from MSD, while bie also appears as a less frequent 
variant both in the nominative and the accusative cases. The genitive form beora in the samples from MSC appears to be dominant much like the form in the samples from MSB, suggesting a possible connection between the two copies. More generally, the variants that are available in the manuscript before c. 890 suggest that this part of MSD also somewhat reflects the original exemplar from which all versions of the Cbronicle are descended (cf. Cubbin 1996). The elements above feed into the patterns identified in work that has focussed primarily on the sources, chronology and text-history of the Chronicle, especially owed to Bately (1978, 1979a, 1979b, 1985, 1991, 2003) and Dumville (1983, 1985, 1986); cf. also Lutz (1981, 1982) and Meaney (1986). These scholars have often used spelling variation as evidence for crosstextual influences in the process of copying and transcribing the Chronicle but have never elaborated on the significance of such a promising category of words like pronouns, and research in cross-textual influences has in fact lost centrality over the last two decades.

While work on spellings and textual relationships in the Chronicle has recently slowed down considerably, the last few years have seen an outbreak of research work in Old English pronouns (cf. e.g. Megginson 1994; Howe 1996; van Bergen 2000; Ohkado 2001; Seppänen 2004; Koopman 2005; Alcorn 2009, 2014; Rusten 2013; Cole 2017; and van Kemenade 2017, to name only a few). The considerable increase in research output with focus on Old English pronouns demonstrates a growing awareness of the potential of pronouns as first-order witnesses of historical change in early English, yet no work has so far focussed on spelling variation in pronouns and issues of elaboration and power. In general, changes affecting pronouns are more likely to reflect conscious attempts to change forms, rather than occasional scribal errors owed to uncertainty or inexperience, or solely passive influences from earlier ancestor or contemporary manuscripts. Pronouns are highly frequent forms and, as such, they are expected to be more resilient to spelling change than other word classes and they generally retain forms longer than the rest of the vocabulary (Lehmann 1992: 108f, Howe 1996: 55). Given the general tendency of pronouns to resist spelling variation, the preponderance of spelling variation in pronoun forms could be explained at least partially as a sign of a conscious willingness from individual scribes to engage with individual attempts to elaborate regularisation in core areas of the language, as a response to the pressures for standardisation (cf. Horobin 2013: 66 on 'elaboration'). The process of spelling regularisation was most likely the product of a conscious willingness to create a prestigious variety that would reflect the grandeur and 
power of the court as well as Winchester and the surrounding scriptoria (cf. Hofstetter 1988: 161). This hypothesis still remains relevant in the face of the possibility that the 'common stock' of the annals up to $c$. 890-891 may have been the product of scribal activity undergoing at the court of King Alfred the Great under commission by the king himself, and only subsequently distributed among and stored in the various scriptoria identified in Table 1 (cf. Scharer 1996, Abels 1998, Brooks 2011). If this possibility was true, copies of the annals were probably used as tokens for the king and the court entourage to gift to monasteries and as a means of 'propaganda', usually to establish or reaffirm power and favour (Pratt 2014). Regardless of where the copies originated, personal pronouns appear to have an important functional role in the context of the samples in question and of the common stock more generally, as they often refer to royal figures or a range of individuals closely related to the king's court, whether by family lineage or simply historically and geographically (cf. Sheppard 2004 on collective identity in the Chronicle).

The centrality of third-person pronouns linguistically and ideologically, both in the eyes of the writer and in those of the reader, may have also constituted the most suitable ground for scribes (who were mostly learned men of the church) to express their favour towards or dissent against the political entourage of the time and any rivalry with other monasteries and scriptoria. In other words, any conscious attempts to systematically control morphological forms and their spellings could also be related to issues of intellectual identity within an individual scriptorium or between two or more different scriptoria, where the scribes may have been not only participating to the requirement of spelling regularisation, but also competing with each other for the same goal. In the samples collected from MSA (Winchester) and from MSB (Abingdon), the spread of each dominant case form appears to also involve a levelling of spelling contrast (e.g. biene and biera in MSA and bine and beora in MSB), which could indicate different, yet relatively consistent attempts to control forms while them potentially representing phonological diversification. In light of these remarks, a comparison of pronoun practices between MSB and MSC is also interesting, as both MSB and MSC are traditionally thought to derive from or be destined to Abingdon Abbey, which means that the scribe from the samples in MSC may have been more likely to have had access to MSB, while still producing a great deal more variation than the samples from MSB. The most traditional scenario to account for the discrepancies between MSB and MSC is the possibility that MSC may have actually not been compared to MSB at all, but solely derived from a lost 
ancestor copy. The dominant forms bira, biera and byra in MSC recall the forms biera in MSA but not heora in MSB, which probably represents a phonological change (see below). According to Bately (1991: 20-21), heora may have existed in an ancestor copy one or two removes from MSB, which means that the sampled section from MSC may have been copied from an even earlier manuscript. However, the presence of forms like beora, bie and bine in MSC also testify some degree of familiarity with the spellings in use in the samples from MSB, as well as a more or less homogenous attempt to spelling, which can hardly be ignored. In view of these considerations, the MSC scribe may have attempted to set his own version of the standard IWS spelling of pronouns as non-identical to MSB (perhaps taking into account other levels of the language, like form and style, as contextual deciders for pronoun variants) at a moment in time where IWS was already well underway and individual scribes may not necessarily have agreed with the spellings used more than seventy years earlier. Interestingly, MSC is thought to have been hostile to the house of Godwine, which is against the supposed cordial relations of Abingdon with the same house of Godwine (cf. Baxter 2007: 1194). Even though the anti-Godwinist stance becomes more relevant towards the end of MSC, this attitude may be read as a more implicit indication of the whole manuscript's contextual affiliation, if we consider the possibility that issues related to intellectual identity were expressed not haphazardly in fragmented manuscript sections but rather in more or less meaningful continuity contexts tied to the history of each individual manuscript. The revised spellings therefore may be read as a willingness to take a stance against the previous MSB copy and the views of the scribe who compiled the same sections. Along these same lines of interpretation, differences in the spellings between MSD and the other copies may also be linked to matters of intellectual identity: if we assume that MSD probably originated in Mercia (which is a matter of controversy as mentioned above, but still a strong possibility), then we should also consider that the Mercian dialect of the Midlands appears to have exerted a rival pressure on IWS, reinforced by the prestige of the Lichfield monastery (cf. Horobin 2013: 67). Although the samples do not necessarily provide evidence of any strong Mercian dialectal influence, the rivalry may have resulted in semi-autonomous attempts to establish a regularised IWS spelling, while also inevitably reflecting the influence of ancestor or more contemporary West Saxon copies. Some of these factors certainly deserve further discussion and exploration as they have the potential to reaffirm the linguistic role of scribes and scriptoria as more active 
centres of intellectual and political engagement. They also enable us to bridge our linguistic field with work conducted on the Chronicle from wholly extralinguistic points of view, focussed on recent interpretations of the annals as panegyrical and functional to the political and religious environment in which they were written (cf. Bredehoft 2001, Sheppard 2004, Jorgensen 2010b, Clarke 2012, Smith 2012, Sparks 2012).

Regardless of the complexity of all possible factors concurring as triggers of spelling variation, all levels of interpretations for the variations in pronouns can be combined with questions related to the traditional phonological understanding of the spelling irregularity. In particular, the $<\mathrm{eo}>$ forms, which have been found in words such as heora, appear to be the result of backumlaut, a process which spread relatively quickly in West Saxon (diphtongisation of /i/ before back vowel in the following syllable: *bire > biora; by a later development, io > eo in WS, see Hogg 1992: §§5.146, 5.155; Colman 1997, note also word-final $e>a$ ). The fact that back-umlaut has spread rather unevenly across the pronouns seems an intriguing scenario that warrants further investigation and may indeed be connected with the interplay of other extra-linguistic factors hypothesised in these notes, or questions related to functional analogy and morphological levelling. While the patterns drawn from the selected samples already provide interesting insights into the manuscript copies, a more extensive, comparative analysis of pronoun spellings across all surviving copies of the Chronicle promises to give some tantalising additional perspectives into the linguistic significance of the common stock. A more extensive cross-textual analysis of variation in pronouns would allow for the investigation of largely unexplored questions from a linguistic point of view and would compensate for the dominant extra-linguistic focus on issues related to identity, historiography and history (see e.g. Stafford 2007). In addition, a multilayered interpretation of spelling evidence would contribute to bringing the discussion of spellings in the Cbronicle more in line with recent trends in historical sociolinguistics (cf. Condorelli \& Rutkowska forthcoming), and it is hoped that my notes will inspire future scholars to follow these trends. 


\section{References}

\section{Primary sources}

Bately, J. M. ed. 1986: The Anglo-Saxon Chronicle: A Collaborative Edition. Vol. 3. Cambridge, D. S. Brewer (MSA).

Cubbin, G. P. ed. 1996: The Anglo-Saxon Chronicle: A Collaborative Edition. Vol. 6. Cambridge, D. S. Brewer (MSD).

Dumville, D. \& S. Keynes gen. eds. 1983-2001: The Anglo-Saxon Chronicle: A Collaborative Edition. Vols. 3-6. Cambridge, D. S. Brewer.

O'Brien O'Keefe, K. ed. 2001: The Anglo-Saxon Chronicle: A Collaborative Edition. Vol. 5. Cambridge, D. S. Brewer (MSC).

Taylor, S. ed. 1983: The Anglo-Saxon Chronicle: A Collaborative Edition. Vol. 4. Cambridge, D. S. Brewer (MSB).

The texts above are printed editions of the following manuscripts:

Cambridge, Corpus Christi College, MS 173 (MSA).

London, British Library, MS Cotton Tiberius A. vi (MSB).

London, British Library, MS Cotton Tiberius B. iv (MSC).

London, British Library, MS Cotton Tiberius B. i (MSD).

\section{Facsimile digital copies}

Cambridge, Corpus Christi College, MS 173, Parker Library on the Web, https://parker.stanford.edu/parker/actions/page.do?forward=home [accessed 11 April 2018].

di Paolo Healey, A. \& R. L. Venezky eds. 1980: A Microfiche Concordance to Old English. Toronto, Dictionary of Old English Project, Centre for Medieval Studies.

MS Cotton Tiberius A. vi, B. iv and B. i, British Library, https://www.bl.uk/manuscripts/ [accessed 11 April 2018].

\section{Secondary sources}

Abels, R. P. 1998: Alfred the Great: War, Kinship and Culture in Anglo-Saxon England (The Medieval World). London, Longman.

Alcorn, R. 2009: Grammatical Person and the Variable Syntax of Old English Personal Pronouns. English Language and Linguistics 13.3: 433-451.

Alcorn, R. 2014: Pronoun Placement and Pronoun Case in Old English. Neuphilologische Mitteilungen 114.4: 455-472. 
Bately, J. 1978: The Compilation of the Anglo-Saxon Chronicle, 60 BC to AD 890: Vocabulary as Evidence. Proceedings of the British Academy 64: 93-129.

Bately, J. 1979a: World History in the Anglo-Saxon Chronicle: Its Sources and its Separateness from the Old English Orosius. Anglo-Saxon England 8: 177-194.

Bately, J. 1979b: Bede and the Anglo-Saxon Chronicle. In M. H. King \& W. M. Stevens eds. Saints, Scholars and Heroes: Studies in Medieval Culture in Honour of Charles W. Jones. Collegeville, Hill Monastic Manuscript Library, Saint John's Abbey and University: 233-254.

Bately, J. 1985: The Compilation of the Anglo-Saxon Chronicle Once More. Leeds Studies in English n.s. 16: 7-26.

Bately, J. 1991: The Anglo-Saxon Chronicle: Texts and Textual Relationships. Reading, Graduate Centre for Medieval Studies, University of Reading.

Bately, J. 2003: Manuscript Layout and the Anglo-Saxon Chronicle. In D. Scragg ed. Textual and Material Culture in Anglo-Saxon England: Thomas Northcote Toller and the Toller Memorial Lectures. Cambridge, Cambridge University Press: 1-21.

Baxter, S. 2007: MSC of the Anglo-Saxon Chronicle and the Politics of Mid-Eleventh Century England. The English Historical Review 499: 1189-1227.

van Bergen, L. 2000: Pronouns and Word Order in Old English, with Particular Reference to the Indefinite Pronoun Man. London, Routledge.

Bredehoft, T. A. 2001: Textual Histories: Readings in the Anglo-Saxon Chronicle. Toronto, University of Toronto Press.

Brooks, N. 2011: Why is the "Anglo-Saxon Chronicle" about Kings?. Anglo-Saxon England 39: 43-70.

Campbell, A. 1959: Old English Grammar. Oxford, Clarendon Press.

Clarke, C. A. M. 2012: Writing Power in Anglo-Saxon England: Texts, Hierarchies, Economies. Woodbridge, Boydell \& Brewer.

Cole, M. 2017: Pronominal Anaphoric Strategies in the West Saxon Dialect of Old English. English Language and Linguistics 21.2: 381-408.

Colman, F. 1985: Old English ie: Quid est?. Lingua 67: 1-23.

Colman, F. 1987: The Phonology and Morphology of an Old English Digraph: ie. In J. Anderson \& J. Durand eds. Explorations in Dependency Phonology. Dordrecht, Foris: 49-77.

Colman, F. 1988: Luick and Templates: Some (Other) Old English Digraphs. In D. Kastovsky, G. Bauer \& J. Fisiak eds. Luick Revisited: Papers Read at the LuickSymposium at Schloss Lichtenstein 15-18.9.1985. Tubingen, Narr: 139-158.

Colman, F. 1992: Money Talks: Reconstructing Old English. Berlin \& New York, Mouton de Gruyter.

Colman, F. 1994: On the Morphology of Old English Word Stress. Lingua 92: 107147.

Colman, F. 1997: Old English <ie>: That is (,) An Orthographic Problem (Noch Einmal). Studia Anglica Posnaniensia 31: 29-39. 
Condorelli, M. \& H. Rutkowska (with M. Lazar et al.) Forthcoming: Introduction. In M. Condorelli ed. Advances in Historical Orthography, c. 1500-1800. Cambridge, Cambridge University Press.

CoNE, Corpus of Narrative Etymologies. Edinburgh, University of Edinburgh. http://www.lel.ed.ac.uk/ihd/CoNE/CoNE.html [accessed 11 April 2018].

Dumville, D. 1983: Some Aspects of Annalistic Writing at Canterbury in the Eleventh and Early Twelfth Centuries. Peritia 2: 23-57.

Dumville, D. 1985: The West Saxon Genealogical Regnal List and the Chronology of Early Wessex. Peritia 4: 21-66.

Dumville, D. 1986: The West Saxon Genealogical Regnal List: Manuscripts and Texts. Anglia 104: 1-32.

Fulk, R. D. 2012: An Introduction to Middle English: Grammar and Texts. Peterborough, Broadview Press.

Gneuss, H. 1986: The Old English Language. In M. Godden \& M. Lapidge eds. The Cambridge Companion to Old English Literature. Cambridge, Cambridge University Press: 23-54.

Gradon, P. 1962: Studies in Late West Saxon Labialization and Delabialization. In N. Davis \& C. L. Wrenn eds. English and Medieval Studies Presented to J. R. R. Tolkien. London, Allen and Unwin: 63-76.

Hoad, T. F. 2014: West Saxon Dialect. In M. Lapidge, J. Blair, S. Keynes \& D. Scragg eds. The Wiley Blackwell Encyclopedia of Anglo-Saxon England. 2nd ed. Oxford, Blackwell.

Hofstetter, W. 1988: Winchester and the Standardization of Old English Vocabulary. Anglo-Saxon England 17: 139-161.

Hogg, R. M. 1992: A Grammar of Old English, Vol. 1: Phonology. Oxford, Blackwell.

Horobin, S. 2013: Does Spelling Matter?. Oxford, Oxford University Press.

Horobin, S. \& J. Smith. 2002: An Introduction to Middle English. Edinburgh, Edinburgh University Press.

Howe, S. 1996: The Personal Pronouns in the Germanic Languages: A Study of Personal Pronoun Morphology and Change in the Germanic Languages from the First Records to the Present Day. Berlin \& New York, Walter de Gruyter.

Jorgensen, A. 2010a: Introduction: Reading the Anglo-Saxon Chronicle. In A. Jorgensen ed. Reading The Anglo-Saxon Chronicle: Language, Literature, History. Turnhout, Brepols Publishers: 1-28.

Jorgensen, A. ed. 2010b: Reading The Anglo-Saxon Chronicle: Language, Literature, History. Turnhout, Brepols Publishers.

van Kemenade, A. 2017: A Response to Cole. English Language and Linguistics 21.2: 409-411.

Ker, N. R. 1957: Catalogue of Manuscripts Containing Anglo-Saxon. Vols. 1-2. Oxford, Oxford University Press. 
Kim, S-S. 1984: Old English <ie> and its Phonetic Identification. In N. F. Blake \& C. Jones eds. English Historical Linguistics: Studies in Development. Sheffield, CECTAL: 24-43.

Koopman, W. 2005: Transitional Syntax: Postverbal Pronouns and Particles in Old English. English Language and Linguistics 9.1: 47-62.

Lass, R. 1994: Old English: A Historical Linguistic Comparison. Cambridge, Cambridge University Press.

Lass, R. \& M. Laing 2005: Are Front Rounded Vowels Retained in West Midland Middle English?. In N. Ritt \& H. Schendl eds. Retbinking Middle English: Linguistic and Literary Approaches. Frankfurt am Main, Peter Lang: 280-290.

Lehmann, W. P. 1992: Historical Linguistics. 3rd ed. London \& New York, Routledge.

Lewenz, M. A. 1908: West Germanic "I" in Old English Saxon Dialects. The Modern Language Review 3: 278-286.

Lutz, A. 1981: Die Version G der Angelsachsischen Chronik: Rekonstruktion und Edition. Munich, Fink.

Lutz, A. 1982: Das Studium der Angelsächsischen Chronik im 16. Jarhhundert: Nowell und Joscelyn. Anglia 100: 301-356.

Meaney, A. 1986: St Neots, Æthelweard and the Compilation of the Anglo-Saxon Chronicle: A Survey. In P. E. Szarmach ed. Studies in Earlier Old English Prose: Sixteen Original Contributions. Albany, State University of New York Press: 193243.

Megginson, D. 1994: He (pl) and Other New Old English Pronouns. American Notes and Queries 7.1: 6-13.

Ohkado, M. 2001: The Position of Subject Pronouns and Finite Verbs in Old English. Folia Linguistica Historica 22: 255-276.

Pilch, H. 1970: Altenglische Grammatik. Munich, Max Hueber.

Pratt, D. 2014: Kings and Books in Anglo-Saxon England. Anglo-Saxon England 43: 297-377.

Plummer, C. [D. Whitelock ed.] 1979: Two of the Anglo-Saxon Chronicles Parallel, II. English Historical Documents, c. 500-1042. 2nd rev. ed. Oxford, Oxford University Press.

Rusten, K. A. 2013: Empty Referential Subjects in Old English Prose: A Quantitative Analysis. English Studies 94.8: 970-992.

Scharer, A. 1996: The Writing of the History at King Alfred's Court. Early Medieval Europe 5: 177-206.

Seppänen, A. 2004: The Old English Relative pe. English Language and Linguistics 8.1: 71-102.

Sheppard, A. 2004: Families of the King: Writing Identity in the Anglo-Saxon Chronicle. Toronto, University of Toronto Press.

Smith, S. T. 2012: Land and Book Literature and Land Tenure in Anglo-Saxon England. Toronto, University of Toronto Press. 
Sparks, N. A. 2012: Textual Histories of the Anglo-Saxon Chronicle: The Alfredian Common Stock. (MSS ABCG, with ref. to DEF), to AD 892. (Ph.D. dissertation.) Cambridge, University of Cambridge.

Stafford, P. 2007: The Anglo-Saxon Chronicles, Identity and the Making of England. The Haskins Society Journal 19: 28-50.

Voss, M. 1995: Traditional Notes on Old English Palatal Diphthongisation. Vienna English Working Papers 4.1: 57-71. 


\section{Appendix 1}

The asterisk $\left(^{*}\right)$ indicates a new form introduced by the later scribes instead of the original corresponding word used in MSA. The possible reasons for the change of form may include difficulties in choosing a variant form, with potential ties to form and style.

\begin{tabular}{|c|c|c|c|c|c|c|c|}
\hline \multicolumn{2}{|r|}{ MSA } & \multicolumn{2}{|r|}{ MSB } & \multicolumn{2}{|r|}{ MSC } & \multicolumn{2}{|r|}{ MSD } \\
\hline Line & Word & Line & Word & Line & Word & Line & Word \\
\hline \multicolumn{2}{|r|}{ [755] } & \multicolumn{2}{|r|}{ [755] } & \multicolumn{2}{|r|}{ [755] } & \multicolumn{2}{|r|}{ [755] } \\
\hline $\begin{array}{l}\text { Line } \\
4\end{array}$ & hiene & $\begin{array}{l}\text { Line } \\
4 \\
\end{array}$ & hine & $\begin{array}{l}\text { Line } \\
4 \\
\end{array}$ & hine & $\begin{array}{l}\text { Line } \\
4 \\
\end{array}$ & hine \\
\hline $\begin{array}{l}\text { Line } \\
5\end{array}$ & hiene & $\begin{array}{l}\text { Line } \\
5\end{array}$ & hine & $\begin{array}{l}\text { Line } \\
5 \\
\end{array}$ & hine & $\begin{array}{l}\text { Line } \\
5\end{array}$ & hine \\
\hline $\begin{array}{l}\text { Line } \\
16\end{array}$ & hie & $\begin{array}{l}\text { Line } \\
16 \\
\end{array}$ & hie & $\begin{array}{l}\text { Line } \\
14 \\
\end{array}$ & hi & $\begin{array}{l}\text { Line } \\
15 \\
\end{array}$ & hy \\
\hline $\begin{array}{l}\text { Line } \\
17 \\
\end{array}$ & hie & $\begin{array}{l}\text { Line } \\
17 \\
\end{array}$ & hie & $\begin{array}{l}\text { Line } \\
15 \\
\end{array}$ & hi & $\begin{array}{l}\text { Line } \\
16 \\
\end{array}$ & heo \\
\hline $\begin{array}{l}\text { Line } \\
21\end{array}$ & hiera & $\begin{array}{l}\text { Line } \\
19\end{array}$ & heora & $\begin{array}{l}\text { Line } \\
17\end{array}$ & $\mathrm{pa}^{*}$ & $\begin{array}{l}\text { Line } \\
19\end{array}$ & heora \\
\hline $\begin{array}{l}\text { Line } \\
21 \\
\end{array}$ & hiera & $\begin{array}{l}\text { Line } \\
20 \\
\end{array}$ & heora & $\begin{array}{l}\text { Line } \\
18 \\
\end{array}$ & hira & $\begin{array}{l}\text { Line } \\
20 \\
\end{array}$ & heora \\
\hline $\begin{array}{l}\text { Line } \\
22 \\
\end{array}$ & hie & $\begin{array}{l}\text { Line } \\
21\end{array}$ & hie & $\begin{array}{l}\text { Line } \\
18 \\
\end{array}$ & hi & $\begin{array}{l}\text { Line } \\
20 \\
\end{array}$ & hie \\
\hline $\begin{array}{l}\text { Line } \\
23\end{array}$ & hie & $\begin{array}{l}\text { Line } \\
22 \\
\end{array}$ & hie & $\begin{array}{l}\text { Line } \\
19 \\
\end{array}$ & hi & $\begin{array}{l}\text { Line } \\
21 \\
\end{array}$ & heo \\
\hline $\begin{array}{l}\text { Line } \\
24 \\
\end{array}$ & gehierdun & $\begin{array}{l}\text { Line } \\
23 \\
\end{array}$ & gehyrdon & $\begin{array}{l}\text { Line } \\
20 \\
\end{array}$ & gehyrdon & $\begin{array}{l}\text { Line } \\
22 \\
\end{array}$ & gehyrdon \\
\hline $\begin{array}{l}\text { Line } \\
26 \\
\end{array}$ & hie & $\begin{array}{l}\text { Line } \\
25 \\
\end{array}$ & hie & $\begin{array}{l}\text { Line } \\
22 \\
\end{array}$ & hi & $\begin{array}{l}\text { Line } \\
24 \\
\end{array}$ & hi \\
\hline $\begin{array}{l}\text { Line } \\
30 \\
\end{array}$ & hiera & $\begin{array}{l}\text { Line } \\
29 \\
\end{array}$ & heora & $\begin{array}{l}\text { Line } \\
26 \\
\end{array}$ & hyra & $\begin{array}{l}\text { Line } \\
28 \\
\end{array}$ & heora \\
\hline $\begin{array}{l}\text { Line } \\
31 \\
\end{array}$ & hie & $\begin{array}{l}\text { Line } \\
30 \\
\end{array}$ & hie & $\begin{array}{l}\text { Line } \\
26 \\
\end{array}$ & hi & $\begin{array}{l}\text { Line } \\
29 \\
\end{array}$ & hi \\
\hline $\begin{array}{l}\text { Line } \\
32 \\
\end{array}$ & hiera & $\begin{array}{l}\text { Line } \\
30 \\
\end{array}$ & heora & $\begin{array}{l}\text { Line } \\
27 \\
\end{array}$ & hira & $\begin{array}{l}\text { Line } \\
29 \\
\end{array}$ & heora \\
\hline
\end{tabular}




\begin{tabular}{|c|c|c|c|c|c|c|c|}
\hline $\begin{array}{l}\text { Line } \\
33\end{array}$ & hie & $\begin{array}{l}\text { Line } \\
32\end{array}$ & hie & $\begin{array}{l}\text { Line } \\
28\end{array}$ & hi & $\begin{array}{l}\text { Line } \\
30\end{array}$ & hie \\
\hline $\begin{array}{l}\text { Line } \\
34 \\
\end{array}$ & hiera & $\begin{array}{l}\text { Line } \\
32\end{array}$ & heora & $\begin{array}{l}\text { Line } \\
29 \\
\end{array}$ & hira & $\begin{array}{l}\text { Line } \\
31\end{array}$ & heora \\
\hline $\begin{array}{l}\text { Line } \\
34\end{array}$ & hie & $\begin{array}{l}\text { Line } \\
33\end{array}$ & hie & $\begin{array}{l}\text { Line } \\
29 \\
\end{array}$ & hi & $\begin{array}{l}\text { Line } \\
31\end{array}$ & hi \\
\hline $\begin{array}{l}\text { Line } \\
35\end{array}$ & hie & $\begin{array}{l}\text { Line } \\
34\end{array}$ & hie & $\begin{array}{l}\text { Line } \\
30 \\
\end{array}$ & hi & $\begin{array}{l}\text { Line } \\
32\end{array}$ & hi \\
\hline $\begin{array}{l}\text { Line } \\
35\end{array}$ & hiera & $\begin{array}{l}\text { Line } \\
34\end{array}$ & heora & $\begin{array}{l}\text { Line } \\
30\end{array}$ & hyra & $\begin{array}{l}\text { Line } \\
32\end{array}$ & heora \\
\hline $\begin{array}{l}\text { Line } \\
35\end{array}$ & hie & $\begin{array}{l}\text { Line } \\
34\end{array}$ & hie & $\begin{array}{l}\text { Line } \\
30\end{array}$ & hi & $\begin{array}{l}\text { Line } \\
33\end{array}$ & hi \\
\hline $\begin{array}{l}\text { Line } \\
36 \\
\end{array}$ & hie & $\begin{array}{l}\text { Line } \\
35 \\
\end{array}$ & hie & $\begin{array}{l}\text { Line } \\
30 \\
\end{array}$ & hie & $\begin{array}{l}\text { Line } \\
33\end{array}$ & hi \\
\hline $\begin{array}{l}\text { Line } \\
36\end{array}$ & hiera & $\begin{array}{l}\text { Line } \\
35\end{array}$ & heora & $\begin{array}{l}\text { Line } \\
31 \\
\end{array}$ & hiera & $\begin{array}{l}\text { Line } \\
34\end{array}$ & heora \\
\hline $\begin{array}{l}\text { Line } \\
38 \\
\end{array}$ & hie & $\begin{array}{l}\text { Line } \\
37\end{array}$ & hie & $\begin{array}{l}\text { Line } \\
32 \\
\end{array}$ & hi & $\begin{array}{l}\text { Line } \\
35\end{array}$ & heo \\
\hline $\begin{array}{l}\text { Line } \\
38\end{array}$ & hie & $\begin{array}{l}\text { Line } \\
37\end{array}$ & hie & $\begin{array}{l}\text { Line } \\
32\end{array}$ & hie & $\begin{array}{l}\text { Line } \\
35\end{array}$ & hi \\
\hline $\begin{array}{l}\text { Line } \\
38\end{array}$ & hie & $\begin{array}{l}\text { Line } \\
37\end{array}$ & hie & $\begin{array}{l}\text { Line } \\
32\end{array}$ & pxs* & $\begin{array}{l}\text { Line } \\
35\end{array}$ & hit* \\
\hline $\begin{array}{l}\text { Line } \\
40\end{array}$ & hie & $\begin{array}{l}\text { Line } \\
38\end{array}$ & hie & $\begin{array}{l}\text { Line } \\
34\end{array}$ & hie & $\begin{array}{l}\text { Line } \\
37\end{array}$ & hy \\
\hline $\begin{array}{l}\text { Line } \\
41\end{array}$ & hie & $\begin{array}{l}\text { Line } \\
39 \\
\end{array}$ & hie & \begin{tabular}{|l} 
Line \\
34 \\
\end{tabular} & hie & $\begin{array}{l}\text { Line } \\
37 \\
\end{array}$ & hi \\
\hline $\begin{array}{l}\text { Line } \\
46\end{array}$ & hiera & $\begin{array}{l}\text { Line } \\
44\end{array}$ & heora & $\begin{array}{l}\text { Line } \\
39 \\
\end{array}$ & heora & $\begin{array}{l}\text { Line } \\
42\end{array}$ & heora \\
\hline $\begin{array}{l}\text { Line } \\
48 \\
\end{array}$ & Miercna & $\begin{array}{l}\text { Line } \\
46\end{array}$ & Myrcna & $\begin{array}{l}\text { Line } \\
40 \\
\end{array}$ & Myrcna & $\begin{array}{l}\text { Line } \\
43 \\
\end{array}$ & Mearcna \\
\hline \multicolumn{2}{|r|}{ [871] } & \multicolumn{4}{|c|}{$[872]$ for $[871]$} & \multicolumn{2}{|r|}{$[871]$} \\
\hline $\begin{array}{l}\text { Line } \\
3\end{array}$ & hie & $\begin{array}{l}\text { Line } \\
3 \\
\end{array}$ & hie & \begin{tabular}{|l} 
Line \\
3 \\
\end{tabular} & hie & $\begin{array}{l}\text { Line } \\
3 \\
\end{array}$ & hie \\
\hline $\begin{array}{l}\text { Line } \\
5\end{array}$ & fierd & $\begin{array}{l}\text { Line } \\
6\end{array}$ & fyrd & $\begin{array}{l}\text { Line } \\
6 \\
\end{array}$ & fyrd & $\begin{array}{l}\text { Line } \\
6\end{array}$ & fyrd \\
\hline
\end{tabular}




\begin{tabular}{|c|c|c|c|c|c|c|c|}
\hline $\begin{array}{l}\text { Line } \\
11\end{array}$ & hie & $\begin{array}{l}\text { Line } \\
12\end{array}$ & hie & $\begin{array}{l}\text { Line } \\
10\end{array}$ & hi & $\begin{array}{l}\text { Line } \\
11\end{array}$ & hi \\
\hline $\begin{array}{l}\text { Line } \\
18\end{array}$ & gefliemde & $\begin{array}{l}\text { Line } \\
19\end{array}$ & geflymdon & $\begin{array}{l}\text { Line } \\
17\end{array}$ & geflymde & $\begin{array}{l}\text { Line } \\
18\end{array}$ & geflymde \\
\hline $\begin{array}{l}\text { Line } \\
24\end{array}$ & hie & $\begin{array}{l}\text { Line } \\
24\end{array}$ & hie & $\begin{array}{l}\text { Line } \\
22\end{array}$ & hie & $\begin{array}{l}\text { Line } \\
23\end{array}$ & hi \\
\hline $\begin{array}{l}\text { Line } \\
24\end{array}$ & hie & $\begin{array}{l}\text { Line } \\
25\end{array}$ & hie & $\begin{array}{l}\text { Line } \\
22\end{array}$ & hie & $\begin{array}{l}\text { Line } \\
24\end{array}$ & hi \\
\hline $\begin{array}{l}\text { Line } \\
24\end{array}$ & gefliemdon & $\begin{array}{l}\text { Line } \\
25 \\
\end{array}$ & geflymdan & \begin{tabular}{|l} 
Line \\
22 \\
\end{tabular} & geflymdon & $\begin{array}{l}\text { Line } \\
24\end{array}$ & geflymdon \\
\hline $\begin{array}{l}\text { Line } \\
34\end{array}$ & gefliemde & $\begin{array}{l}\text { Line } \\
35\end{array}$ & geflymde & \begin{tabular}{|l} 
Line \\
31
\end{tabular} & geflymde & $\begin{array}{l}\text { Line } \\
33\end{array}$ & geflymde \\
\hline \multicolumn{2}{|r|}{ [885] } & \multicolumn{4}{|c|}{ [886] for $[885]$} & \multicolumn{2}{|r|}{ [885] } \\
\hline $\begin{array}{l}\text { Line } \\
3\end{array}$ & hie & $\begin{array}{l}\text { Line } \\
3\end{array}$ & hie & $\begin{array}{l}\text { Line } \\
3\end{array}$ & hie & $\begin{array}{l}\text { Line } \\
2\end{array}$ & hi \\
\hline $\begin{array}{l}\text { Line } \\
3\end{array}$ & hie & $\begin{array}{l}\text { Line } \\
3\end{array}$ & hie & $\begin{array}{l}\text { Line } \\
3\end{array}$ & hie & $\begin{array}{l}\text { Line } \\
3\end{array}$ & hi \\
\hline $\begin{array}{l}\text { Line } \\
5\end{array}$ & fierde & $\begin{array}{l}\text { Line } \\
4\end{array}$ & fyrde & \begin{tabular}{|l} 
Line \\
4 \\
\end{tabular} & fyrde & $\begin{array}{l}\text { Line } \\
4\end{array}$ & fyrde \\
\hline $\begin{array}{l}\text { Line } \\
5\end{array}$ & hiera & $\begin{array}{l}\text { Line } \\
5\end{array}$ & heora & $\begin{array}{l}\text { Line } \\
5\end{array}$ & hyra & $\begin{array}{l}\text { Line } \\
4\end{array}$ & heora \\
\hline $\begin{array}{l}\text { Line } \\
6\end{array}$ & hie & $\begin{array}{l}\text { Line } \\
5\end{array}$ & hie & $\begin{array}{l}\text { Line } \\
5\end{array}$ & hi & $\begin{array}{l}\text { Line } \\
5\end{array}$ & hi \\
\hline $\begin{array}{l}\text { Line } \\
8\end{array}$ & hie & $\begin{array}{l}\text { Line } \\
8 \\
\end{array}$ & hie & \begin{tabular}{|l} 
Line \\
8 \\
\end{tabular} & hi & $\begin{array}{l}\text { Line } \\
7 \\
\end{array}$ & hi \\
\hline $\begin{array}{l}\text { Line } \\
9\end{array}$ & hie & $\begin{array}{l}\text { Line } \\
9 \\
\end{array}$ & hie & \begin{tabular}{|l} 
Line \\
8 \\
\end{tabular} & hie & $\begin{array}{l}\text { Line } \\
8\end{array}$ & hy \\
\hline $\begin{array}{l}\text { Line } \\
11 \\
\end{array}$ & hie & $\begin{array}{l}\text { Line } \\
10\end{array}$ & hie & \begin{tabular}{|l|} 
Line \\
10 \\
\end{tabular} & hie & $\begin{array}{l}\text { Line } \\
10\end{array}$ & hi \\
\hline $\begin{array}{l}\text { Line } \\
12\end{array}$ & hie & $\begin{array}{l}\text { Line } \\
11\end{array}$ & hie & \begin{tabular}{|l} 
Line \\
11 \\
\end{tabular} & hie & $\begin{array}{l}\text { Line } \\
11\end{array}$ & hi \\
\hline $\begin{array}{l}\text { Line } \\
15 \\
\end{array}$ & hiene & $\begin{array}{l}\text { Line } \\
14 \\
\end{array}$ & hine & \begin{tabular}{|l} 
Line \\
13 \\
\end{tabular} & hine & $\begin{array}{l}\text { Line } \\
13\end{array}$ & hine \\
\hline $\begin{array}{l}\text { Line } \\
17 \\
\end{array}$ & hie & $\begin{array}{l}\text { Line } \\
16\end{array}$ & $\mathrm{pa}^{*}$ & \begin{tabular}{|l|} 
Line \\
15 \\
\end{tabular} & $\mathrm{pa}^{*}$ & $\begin{array}{l}\text { Line } \\
15 \\
\end{array}$ & $\mathrm{pa}^{*}$ \\
\hline
\end{tabular}




\begin{tabular}{|l|l|l|l|l|l|l|l|}
\hline $\begin{array}{l}\text { Line } \\
18\end{array}$ & apiestrode & $\begin{array}{l}\text { Line } \\
17- \\
18\end{array}$ & apeostrode & $\begin{array}{l}\text { Line } \\
16\end{array}$ & apystrode & $\begin{array}{l}\text { Line } \\
16\end{array}$ & apystrode \\
\hline $\begin{array}{l}\text { Line } \\
24\end{array}$ & behienan & $\begin{array}{l}\text { Line } \\
23\end{array}$ & beheonan & $\begin{array}{l}\text { Line } \\
21\end{array}$ & beheonan & $\begin{array}{l}\text { Line } \\
22\end{array}$ & beheonan \\
\hline $\begin{array}{l}\text { Line } \\
28\end{array}$ & hie & $\begin{array}{l}\text { Line } \\
27\end{array}$ & hie & $\begin{array}{l}\text { Line } \\
25\end{array}$ & hi & $\begin{array}{l}\text { Line } \\
25\end{array}$ & hy \\
\hline
\end{tabular}

\section{Appendix 2}

Overall number of pronouns spellings in selected sections from MSA, MSB, MSC and MSD. This appendix contains the same pronouns as in Appendix 1, with the exception of newly introduced forms.

MSA

\begin{tabular}{|l|l|l|l|}
\hline $\begin{array}{l}3^{\text {rd }} \text { Person } \\
\text { Nominative Plural }\end{array}$ & $\begin{array}{l}3^{\text {rd }} \text { Person } \\
\text { Accusative Plural }\end{array}$ & $\begin{array}{l}3^{\text {rd }} \text { Person Genitive } \\
\text { Plural }\end{array}$ & $\begin{array}{l}3^{\text {rd }} \text { Person } \\
\text { Masculine } \\
\text { Accusative Singular }\end{array}$ \\
\hline Hie x 27 & Hie x 2 & Hiera x 9 & Hiene x 3 \\
\hline
\end{tabular}

MSB

\begin{tabular}{|l|l|l|l|}
\hline $\begin{array}{l}3^{\text {rd }} \\
\text { Nominative Plural }\end{array}$ & $\begin{array}{l}3^{\text {rd }} \text { Person } \\
\text { Accusative Plural }\end{array}$ & $\begin{array}{l}3^{\text {rd }} \text { Person Genitive } \\
\text { Plural }\end{array}$ & $\begin{array}{l}3^{\text {rd }} \text { Person } \\
\text { Masculine } \\
\text { Accusative Singular }\end{array}$ \\
\hline Hie x 26 & Hie x 2 & Heora x 9 & Hine x 3 \\
\hline
\end{tabular}

MSC

\begin{tabular}{|l|l|l|l|}
\hline $\begin{array}{l}3^{\text {rd }} \text { Person } \\
\text { Nominative Plural }\end{array}$ & $\begin{array}{l}3^{\text {rd }} \text { Person } \\
\text { Accusative Plural }\end{array}$ & $\begin{array}{l}3^{\text {rd }} \text { Person Genitive } \\
\text { Plural }\end{array}$ & $\begin{array}{l}3^{\text {rd }} \text { Person } \\
\text { Masculine } \\
\text { Accusative Singular }\end{array}$ \\
\hline Hi x 15 & Hie x 2 & Hira x 3 & Hine x 3 \\
\hline Hie x 10 & & Hyra x 3 & \\
\hline & & Heora x 1 & \\
\hline & & Hiera x 1 & \\
\hline
\end{tabular}


MSD

\begin{tabular}{|l|l|l|l|}
\hline $\begin{array}{l}3^{\text {rd }} \text { Person } \\
\text { Nominative Plural }\end{array}$ & $\begin{array}{l}3^{\text {rd }} \text { Person } \\
\text { Accusative Plural }\end{array}$ & $\begin{array}{l}3^{\text {rd }} \text { Person Genitive } \\
\text { Plural }\end{array}$ & $\begin{array}{l}3^{\text {rd }} \text { Person } \\
\text { Masculine } \\
\text { Accusative Singular }\end{array}$ \\
\hline Hy x 4 & Hie x 1 & Heora x 9 & Hine x 3 \\
\hline Heo x 3 & & & \\
\hline Hie x 2 & & & \\
\hline Hi x 17 & & & \\
\hline
\end{tabular}

\section{Author's address}

School of Humanities and Social Sciences

University of Central Lancashire

Preston PR1 2HE

UK

received: 2 June 2018

e-mail: MCondorelli@uclan.ac.uk accepted: 28 November 2018 